\title{
Proses Resiliensi Ayah Tunggal yang Memiliki Remaja Autisme
}

\author{
JANNES DINDA TRICIA \& PENNY HANDAYANI* \\ Universitas Katolik Indonesia Atma Jaya
}

\begin{abstract}
ABSTRAK
Kehadiran remaja autisme dapat mempengaruhi rutinitas dan pola hubungan keluarga. Individu membutuhkan kemampuan resiliensi agar dapat bangkit dan bertahan. Penelitian ini bertujuan untuk memaparkan proses resiliensi ayah tunggal yang memiliki remaja autisme. Penelitian ini menggunakan metode kualitatif. Kedua partisipan merupakan ayah tunggal, karena istri meninggal lebih dari dua tahun sebelumnya dan memiliki remaja dengan gangguan autisme. Hasil penelitian menunjukkan kedua partisipan memiliki proses resiliensi yang berbeda, dilihat dari peningkatan pada pemahaman personal, lingkungan yang mendukung, dan kemampuan mengatasi masalah. Perbedaan yang dimaksud adalah kehadiran caregiver yang dimiliki sehingga partisipan kedua membutuhkan usaha yang lebih besar dalam menjalani proses resiliensi. Kesimpulan penelitian ini adalah kedua partisipan sudah mengalami antisipasi grief ketika istri sakit dan terdapat pengalaman mengasuh remaja autisme sehingga dapat membantu proses resiliensi ayah tunggal. Harmonisasi hubungan suami istri sangat diperlukan sedini mungkin sebagai persiapan jika salah satu pasangan meninggal dunia, serta keluarga dan teman diharapkan tetap memberikan dukungan.
\end{abstract}

Kata kunci: autisme, ayah tunggal, remaja, resiliensi

\begin{abstract}
The presence of autistic adolescents can affect the routine and patterns of family relationships. Individuals need resilience in order to rise and survive. This study aimed to describe the resilience process of single fathers who have adolescents with autism. This study used a qualitative method. Both participants are single fathers, and their wives have passed away for more than two years and have a teenager with autism disorders. The results showed that the two participants had a different resilience process, seen from the increase in personal understanding, a supportive environment, and the ability to solve problems. The difference in question is the presence of a caregiver so that the second participant requireed greater effort in undergoing the resilience process. The conclusion of this study is that the two participants have experienced grief anticipation when their wives were ill and there were experiences of caring for adolescents with autism so that they can help the process of single father resilience. Harmonization of the husband and wife relationship is needed as early as possible as a preparation if one partner dies, and family and friends are expected to continue to provide support.
\end{abstract}

Keywords: autism, single father, adolescence, resilience 
INSAN Jurnal Psikologi dan Kesehatan Mental, 2021, Vol. 6(1), 22-42, doi: 10.20473/jpkm.v6i12021.22-43 Dikirimkan: 25 September 2018 Diterima: 4 November 2020 Diterbitkan: 1 Januari 2021

Editor: Rizqy Amelia Zein

*Alamat korespondensi: Jalan Jenderal Sudirman 51, Jakarta 12930 Surel: penny.handayani@atmajaya.ac.id

Naskah ini merupakan naskah dengan akses terbuka dibawah ketentuan the Creative Common Attribution License (http://creativecommons.org/licenses/by/4.0), sehingga penggunaan, distribusi, reproduksi dalam media apapun atas artikel ini tidak dibatasi, selama sumber aslinya disitir dengan baik.

\section{P E N D A H U L U A N}

Tekanan merupakan bagian yang tidak dapat dihindarkan dari kehidupan. Dalam menghadapi tekanan diperlukan kemampuan untuk bangkit dari masalah tersebut. Proses interaksi antara individu dengan lingkungannya dalam menghadapi tekanan untuk mencapai hasil adaptasi positif dDSMisebut sebagai resiliensi (Kumpfer, 1999). Ketika individu mengalami pembentukan kekuatan emosional dan coping yang sehat selama proses mengatasi faktor risiko, maka individu memiliki resiliensi yang tinggi (Richardson, Neiger, Jensen, \& Kumpfer, 1990, dalam Glantz \& Johnson, 2002). Ketika perubahan dan tekanan hidup terjadi begitu cepat, maka seseorang perlu mengembangkan kemampuan dirinya untuk mampu melewati tekanan tersebut secara efektif (Abrams, dalam Singh, Junnarkar, \& Kaur, 2016). Salah satu perubahan dan tekanan hidup yang dialami individu dalam sebuah pernikahan adalah kehilangan pasangan. Hal ini merupakan kondisi yang tidak dapat dicegah (Hurlock, 1999). Dibandingkan perceraian, kematian pasangan dipandang sebagai kejadian hidup yang paling besar potensinya untuk mendatangkan tekanan. Berdasarkan penelitian yang dilakukan oleh Glazer, Clark, Thomas \& Haxton (2010) diketahui bahwa kematian berdampak pada berubahnya pola pengasuhan anak dan hubungan yang dihadapi pasangan yang masih hidup dengan orang lain dan diri sendiri.

Laki-laki sebagai orangtua tunggal lebih berat kehilangan pasangannya daripada wanita (Christieny, 2016). Hal ini disebabkan laki-laki lebih mengandalkan istri dalam hubungan sosial, penanggulangan stres, dan tugas rumah tangga. Selain itu, adanya peran gender membuat laki-laki kurang bebas dalam mengungkapkan emosinya Benner, Lud, Caserta (dalam Berk, 2012). Emosi tersebut terkait dalam dukacita, frustasi, kecemasan, dan beban dalam mengasuh (Apostelina, 2012). Ayah tunggal adalah suatu kondisi yang dialami seorang laki-laki dewasa yang memiliki anak dan bertanggung jawab penuh untuk memelihara anak secara fisik maupun psikologis tanpa adanya pasangan hidup yang diakibatkan kematian pasangan atau perceraian (Lamb, 2010). Adapun budaya patriarki di Indonesia yang mengorientasikan peran laki-laki atau ayah sebagai pencari nafkah di luar rumah. Dengan adanya kematian istri memunculkan stigma ayah sebagai duda, hal ini dapat memunculkan reaksi fisik dan psikologis lebih buruk seperti, sulit menerima keadaan baru, merasa tertekan dan menarik diri dari lingkungan sosial (Christieny, 2016). Keadaan tersebut membuat ayah tunggal memiliki peran ganda. Hal tersebut berkaitan dengan usaha untuk memperoleh pendapatan serta karir yang memuaskan. Di sisi lain, mereka harus memenuhi tanggung jawab sebagai ayah dalam pengasuhan anak.

Selain berfokus pada masalah perkembangan anak, di sisi lain ayah tunggal sedang berjuang mengatasi kehilangan pasangannya dan menghadapi masalah tekanan sosial. Terdapat tekanan dari lingkungan yang meminta ayah tunggal menikah kembali. Tekanan sosial yang paling kuat terjadi pada ayah sebagai orangtua tunggal yang diragukan kemampuannya dalam mengasuh anak dan mengelola rumah tangga (Amato \& Dorius, dalam Lamb, 2010). Secara khusus ketika ayah memiliki anak berkebutuhan khusus diusia remaja, pengasuhan yang diberikan menjadi berbeda. Selaras dengan Hallahan, Kauffman, dan Pullen (dalam Anggreni \& Valentina, 2015), ketika sebuah keluarga memiliki 
anak berkebutuhan khusus akan memiliki kesulitan dan tantangan yang lebih dibandingkan memiliki anak normal. Menurut Mangunsong (2011) anak kebutuhan khusus adalah anak yang mengalami penyimpangan dari rata-rata anak normal dalam hal ciri-ciri mental, kemampuan sensorik, fisik dan neuromuscular, perilaku sosial dan emosional, kemampuan berkomunikasi, maupun kombinasi dua atau lebih dari hal-hal di atas, sejauh ia memerlukan modifikasi dari tugas-tugas sekolah, metode belajar atau pelayanan terkait lainnya yang diajukan untuk mengembangkan potensi atau kapasitasnya secara maksimal. Sedangkan, remaja adalah masa transisi antara masa kanak-kanak dan dewasa yang melibatkan perubahan biologis, kognitif, dan sosio-emosional (Santrock, 2003). Bagi seorang ayah yang memiliki remaja dengan kebutuhan khusus akan memiliki respon emosional yang berbeda terhadap kemampuan mereka untuk memenuhi kebutuhan remaja dan keluarga. Para ayah juga menggambarkan hilangnya ekspektasi secara tiba-tiba sehubungan dengan peran mereka sebagai ayah yang ideal dan sulitnya menerima diagnosa tersebut (Ramchandani, O'Connor, Evans, Heron, Murray, \& Stein, dalam Lamb, 2010).

Salah satu diagnosa remaja berkebutuhan khusus adalah autisme. Menurut Strock, autisme merupakan gangguan yang meliputi area kognitif, emosi, perilaku, sosial, dan ketidakmampuan untuk berinteraksi dengan orang-orang di sekelilingnya (Hallahan \& Kauffman, 2006). Dalam DSM-V simptom-simptom autisme muncul dalam periode perkembangan awal, akan tetapi simtom-simtom tersebut dapat tertutupi atau berkurang karena adanya efek belajar. Remaja autisme akan tumbuh dan berkembang dengan cara yang berbeda dibandingkan dengan remaja normal lainnya. Hal tersebut dapat dilihat berdasarkan karakteristik utama gangguan autisme (Hallahan \& Kauffman, 2006). Salah satu fase perkembangan remaja adalah perubahan dalam hubungan dengan orang lain. Remaja tidak lagi berhubungan hanya dengan individu dari jenis kelamin yang sama tetapi dengan lawan jenis. Dalam pemenuhan kebutuhan seksualitas, remaja autisme memiliki ketertarikan pada orang lain, tetapi gaya ekspresi seksualitas mereka seringkali naif, tidak matang dan tidak sesuai dengan usianya (Schwier \& Hingsburger, dalam Dariany 2015). Selain itu, remaja autisme memiliki kelemahan memersepsikan pesan dan aturan yang berlaku secara sosial, mengakibatkan remaja autisme tidak mampu mengikuti aturan sosial (Dariany, 2015).

Hasil serupa diperoleh oleh Kasari dan Sigman (1997) menemukan bahwa hubungan antara tingkat stres orangtua dengan respon remaja saat berinteraksi (dalam Pisula, 2011). Hal ini disebabkan terbatasnya komunikasi orangtua dengan remaja autisme secara verbal dan nonverbal, seperti gerak tubuh, intonasi, melodi, ritme ucapan, ekspresi wajah, dan postur tubuh. Remaja autisme kesulitan dalam menggunakan komunikasi untuk mengatur hubungan sosial (Walenski, Tager-Flusberg, \& Ullman, 2006, dalam Pisula, 2011). Orangtua dengan remaja yang terdiagnosa autisme akan melakukan penyesuaian hidup terkait dengan menumbuhkan perilaku menantang di rumah dan di depan umum, perasaan dinilai oleh orang lain yang berdampak pada keluarga, seperti merasa terlalu cemas, stres dan kelelahan, perubahan hubungan suami istri, dan dampak terhadap hubungan dengan anak-anak lain (Burrell, Ives, \& Unwin, 2017). Berdasarkan hasil penelitian Hornby (1992, dalam Lamb, 2010) mengenai pengalaman ayah sekitar waktu diagnosa, menunjukkan bahwa ayah mengalami gejala depresi yang meningkat dari waktu ke waktu ketika remaja berkebutuhan khusus mulai beranjak dewasa dan memiliki keterbatasan dalam keterampilan adaptif. Seorang ayah perlu menyesuaikan diri bahwa mereka adalah ayah dari remaja yang memiliki gangguan autisme. Hal ini diperlukan agar ayah dapat memahami bagaimana mereka bersikap dan berperilaku terhadap remaja autisme. Ayah perlu melakukan penyesuaian secara emosional, menerima realitas, memiliki kesadaran intelektual mengenai remaja autisme. Ayah perlu memerhatikan hubungan saudara-saudara remaja autisme. Mereka perlu diberikan pengertian agar dapat menerima keberadaan saudaranya yang berkebutuhan khusus (Mangunsong, 2011).

Berdasarkan fenomena di atas, penelitian ini berfokus pada ayah tunggal yang kehilangan pasangan

INSAN Jurnal Psikologi dan Kesehatan Mental

2021, Vol. 6(1), 22-43

doi: 10.20473/jpkm.v6i12021.22-42

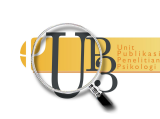


karena meninggal dunia dan bangkit dari kemalangan tersebut, serta menjalani peran baru sebagai orangtua tunggal dalam mengasuh remaja autisme. Penelitian ini dirasa penting karena kemampuan resiliensi sangat dibutuhkan bagi setiap ayah sebagai orangtua tunggal agar memiliki pandangan positif dan mampu menerima kondisi dan peran baru dengan remaja autisme. Peneliti melihat ada batas pada penelitian-penelitian sebelumnya yang melibatkan ayah hanya sebagai partisipan tambahan dan bukan partisipan utama dalam mengasuh remaja autisme, sedangkan ayah tunggal resilien dianggap sudah mengalami proses hingga mencapai hasil adaptasi positif atau resilien.

\section{ME T O D E}

\section{Desain Penelitian}

Pada penelitian ini, metode yang digunakan adalah kualitatif dengan pendekatan naratif. Pendekatan penelitian naratif adalah sebuah pendekatan yang digunakan untuk mendeskripsikan, kehidupan individu, mengumpulkan, dan menceritakan kehidupan individu, serta menuliskan narasi pengalaman individu (Creswell, 2012). Peneliti menggunakan pendekatan naratif karena resiliensi dari Karol Kumpfer merupakan proses dan tidak berjalan secara satu arah. Oleh karena itu, melalui pendekatan naratif peneliti dapat mengetahui proses resiliensi sebelum menerima diagnosa anak autisme, saat menerima diagnosa anak autisme, dan menjadi ayah tunggal setelah istri meninggal.

Peneliti menggunakan resiliensi Karol Kumpfer disebabkan kerangka berpikir Kumpfer merupakan kerangka berpikir yang terintegrasi mencakup stresor, faktor eksternal, karakteristik internal, interaksi antara faktor eksternal dengan karakteristik internal, proses resiliensi, dan hasil adaptasi positif untuk menjelaskan proses resiliensi. Proses resiliensi yang dimaksud peneliti adalah ingin memberikan gambaran proses interaksi antara karakteristik internal dengan lingkungan eksternal yang dialami partisipan sebelum mengetahui diagnosa remaja autisme, ketika mengetahui diagnosa remaja autisme, sebelum istri meninggal hingga menjadi ayah tunggal. Proses dianggap penting karena seseorang harus melewati stresor terlebih dahulu untuk bisa mencapai resiliensi. Penelitian ini menunjukkan bahwa terdapat ayah tunggal yang bertahan dengan status orangtua tunggal dan mengasuh remaja dengan gangguan autisme.

\section{Partisipan}

Karakteristik partisipan utama penelitian ini adalah ayah mengalami kehilangan pasangannya karena meninggal dan memiliki remaja dengan gangguan autisme dan sudah menjadi ayah tunggal minimal dua tahun. Karakteristik partisipan yang dibutuhkan untuk keperluan triangulasi dalam penelitian ini merupakan caregiver remaja autisme partisipan yang membantu mengasuh dan mengetahui proses kehilangan istri partisipan.

\section{Strategi Pengumpulan Data}

Peneliti menggunakan teknik wawancara in-depth interview dengan pertanyaan wawancara bersifat open-ended question. Hal ini bertujuan agar partisipan dapat mengeksplor peristiwa yang dialami. Selain itu, peneliti juga menggunakan metode wawancara nondirective approach agar peneliti tidak membatasi jawaban yang diberikan partisipan. Peneliti tidak hanya mewawancarai satu partisipan melainkan significant others. 


\section{Analisis Data}

Metode analisis data yang digunakan adalah thematic analysis. Hal ini dilakukan agar peneliti dapat mengidentifikasi tema dari hasil pengambilan data dan menyediakan kompleksitas dari sebuah cerita dan memperdalam insight mengenai pemahaman pengalaman seseorang.

\section{HAS IL PENELITIAN}

\section{Partisipan 1}

Aaron dikaruniai tiga orang anak. Pieter merupakan anak pertama Aaron yang mengalami gangguan autisme. Ketika Pieter lahir tidak ada kecurigaan dari dokter atau Aaron mengenai kondisi dan perkembangan Pieter. Saat Pieter berumur 9 bulan, ia dapat memberikan respon tersenyum dan tertawa ketika Aaron dan istri mengajak main peek a boo. Dalam perkembangannya, Pieter juga sudah dapat berjalan namun, kemampuannya dalam berbicara sangat lambat. Ia hanya dapat mengatakan "papa" dan "mama". Hal ini tidak menjadi kekhawatiran bagi Aaron dan istri karena mereka beranggapan bahwa ketika anak mampu berjalan lebih dulu maka kemampuannya dalam berbicara akan lebih lambat. Seiring dengan berjalannya waktu Pieter memunculkan perilaku tertarik terhadap benda-benda yang berputar dan suara nyaring atau keras, seperti suara blender dan kipas angin.

Aaron dan istri belum menyadari gejala-gejala yang dimunculkan oleh Pieter. Ketika Pieter berumur 1 tahun, Aaron dipindahtugaskan oleh tempat ia bekerja dari Makassar ke Jakarta. Ketika mereka pindah ke Jakarta, tante Pieter sering mengunjungi Pieter dan mengikuti perkembangan Pieter. Tante Pieter menyadari perilaku-perilaku yang ditimbulkan Pieter sedikit berbeda dari anak normal lainnya. Suatu hari tante Pieter sedang membaca artikel dalam suatu majalah mengenai karakteristik anak autisme yang ditulis oleh salah satu psikolog ternama. Setelah membaca artikel tersebut, timbul kecurigaan terhadap Pieter dan menyuruh orangtua Pieter untuk membawanya ke psikolog tersebut dan melakukan pemeriksaan.

Kecurigaan yang ditunjukkan tante Pieter mengenai diagnosa autisme dapat menjadi faktor risiko lingkungan eksternal bagi Aaron. Hal ini disebabkan belum adanya kepastian mengenai kondisi Pieter sehingga membuat Aaron dan istri terus memikirkan kondisi Pieter. Melihat kecurigaan dan pendapat tersebut membuat Aaron dan istri tidak menghindari tetapi mencoba mencari tahu dan ingin membuktikan mengenai kondisi Pieter. Pihak ahli melakukan tes sehelai rambut Pieter untuk mendapatkan informasi terkait diagnosa. Diagnosa Pieter memiliki ganggun autisme diberikan ketika Pieter berumur 3 tahun. Aaron dan istri merasa shock, sedih dan bertanya-tanya penyebab Pieter memiliki gangguan autisme. Aaron tidak tahu pasti penyebab Pieter memiliki gangguan autisme yang ia tahu bahwa hal tersebut bukan dari gen atau turunan karena dalam riwayat anggota keluarganya tidak ada yang memiliki gangguan autisme. Aaron sempat mengeluh dan bertanya kepada Tuhan, mengapa anak pertamanya memiliki gangguan autisme dan mengapa harus dirinya yang menerima hal tersebut.

Bagi Aaron menerima kondisi Pieter sangat berat karena belum memiliki pengalaman dalam mengasuh anak dan belum mengatahui cara mengasuh anak autisme. Selain itu, sebagai orangtua yang baru akan memiliki anak pertama pasti memiliki harapan memiliki anak normal dan mempersiapkan cara mengasuh anak normal. Ketidaksiapan yang dialami Aaron dan istri membuat hal tersebut menjadi titik terberat Aaron ketika mengetahui diagnosa Pieter.

Seiring berjalannya waktu, Aaron dan istri menyadari tanggung jawabnya sebagai orangtua dalam mengasuh dan menerima kondisi anak dengan keadaan apapun. Hal lain yang membuat Aaron merasa lebih mudah dalam menerima kondisi Pieter karena ketekunan istri Aaron dalam mencari tahu tentang anak autisme. Aaron mengakui bahwa istrinya sangat ketat dalam menjaga dan mengasuh INSAN Jurnal Psikologi dan Kesehatan Mental 2021, Vol. 6(1), 22-43

doi: 10.20473/jpkm.v6i12021.22-42 
Pieter dalam hal makanan dan memberikan terapi untuk Pieter. Walaupun Aaron bekerja tetapi ia tetap mengetahui perkembangan Pieter dan berusaha untuk meluangkan waktunya untuk Pieter setelah selesai bekerja. Hal ini dilakukan agar dapat membantu istri Aaron dalam mengasuh Pieter. Melihat ketekunan istri Aaron membuat Aaron merasa memiliki support system dan fondasi resiliensi, serta coping yang positif dari istrinya. Resiliensi yang dimiliki istri dapat menjadi pembelajaran bagi Aaron untuk mengalami proses resiliensi. Hal ini membantu Aaron untuk memandang lebih positif ketika melihat kondisi yang dialami. Istri merupakan faktor protektif bagi Aaron.

Dua tahun kemudian, Aaron dan istri ingin memiliki anak ke-2 tetapi terdapat kekhawatiran untuk kondisi anak kedua mereka. Mereka takut anak keduanya memiliki gangguan yang sama. Sebab yang mereka tahu apabila terdapat keluarga yang mengalami kebutuhan khusus maka terdapat kemungkinan kembali untuk mengalami hal yang sama. Aaron dan istri memiliki trauma untuk kondisi anaknya nanti. Seiring berjalannya waktu, keinginan memiliki anak ke-2 dan ke-3 lebih kuat daripada kekhawatiran dan trauma yang dimiliki Aaron dan istri. Maka dari itu, istri Aaron sangat menjaga kandungannya dan memperhatikan setiap perkembangan anak ke-2 dan ke-3.

Kehadiran dan kondisi Bryan yang regular tidak membuat Aaron dan istri mengalihkan perhatian kepada Pieter. Hal ini dilihat dari penerimaan Aaron terhadap kondisi Pieter, ketika teman-teman istri Aaron memasukan anak autisme mereka ke asrama, Aaron menolak untuk memasukan Pieter ke asrama.

Menurut Aaron, Pieter memiliki kondisi yang tidak begitu parah dan Aaron merasa masih sanggup untuk mengasuh Pieter tanpa bantuan orang lain atau pihak lain. Ia juga menganggap bahwa kondisi Pieter tidak mengharuskan ia diasuh di tempat yang berbeda dengan adik-adiknya dan Pieter memiliki hak yang sama dengan adik-adiknya.

Aaron dan istri mengetahui bahwa anak autisme membutuhkan terapi agar kemampuan yang dimiliki dapat berkembang. Aaron dan istri memikirkan pendidikan yang dapat diberikan untuk melatih kemampuan dan kemandirian Pieter. Istri Aaron mencari sekolah, tempat les, dan terapi yang terbaik untuk Pieter dengan harapan bahwa Pieter dapat sembuh dan mengalami perkembangan. Pieter sempat mengalami berpindah-pindah dari satu sekolah ke sekolah lainnya karena istri Aaron merasa sekolah-sekolah tersebut tidak memberikan perkembangan untuk Pieter sehingga Aaron dan istri terus mencari sekolah yang terbaik bagi perkembangan Pieter. Ketika Pieter berumur 20 tahun ia masuk di sekolah berkebutuhan khusus yang sesuai dan terbaik bagi Aaron dan istri hingga saat ini. Kini faktor risiko tersebut sudah berubah menjadi faktor protektif disebabkan Aaron dan istri sudah memiliki tempat yang nyaman dan tidak perlu khawatir untuk pendidikan dan perkembangan Pieter. Saat ini Pieter juga sudah menunjukkan perkembangan dan kemandirian selama sekolah sehingga Aaron tidak begitu khawatir mengenai kondisi dan masa depan Pieter.

Perpindahan sekolah Pieter merupakan environmental modification yang dilakukan oleh Aaron. Ketika Aaron dan istri merasa sekolah Pieter tidak baik untuk perkembangan Pieter, mereka memutuskan untuk pindah ke sekolah yang lebih baik dan dapat memberikan perkembangan bagi Pieter. Aktivitas keseharian Pieter setelah sekolah adalah les dan lanjut terapi dari hari Senin hingga Sabtu. Hal ini dilakukan karena anak autisme membutuhkan intensitas terapi agar Pieter lebih tenang.

Apabila dilihat dari perkembangan Pieter dari masa remaja hingga saat ini, jika Pieter ingin sesuatu, ia tidak dapat mengungkapkannya tetapi langsung menarik seseorang agar ia mendapat apa yang ia mau. Misalnya, menarik anggota keluarganya untuk ke mall. Hal tersebut disebabkan ia kesulitan memahami dan menggunakan bahasa verbal sehingga ia menggunakan bahasa tubuh. Selain itu, jika Pieter ingin makan, ia akan menarik orang yang berada didekatnya untuk mengambilkan makanan untuknya. 
Pieter juga enggan untuk berinteraksi secara aktif dengan orang lain. Perilaku yang dimunculkan oleh Pieter tidak sesuai dengan tugas perkembangan remaja regular. Salah satu tugas perkembangan remaja adalah membangun hubungan dengan orang lain tetapi Pieter enggan untuk berinteraksi dan melakukan hubungan sosial. Pieter juga tidak dapat berbicara dengan jelas hanya dapat menjawab namanya sendiri dan nama anggota keluarganya. Komunikasi dan hubungan sosial yang dimiliki Pieter baik secara verbal maupun non-verbal sangat terbatas. Pieter juga tidak dapat melakukan komunikasi melalui media komunikasi. Ketika Pieter diberikan alat komunikasi, ia hanya menggunakan untuk menonton youtube.

Di kelas Pieter unggul dalam bidang matematika. Ia tidak menggunakan kalkulator untuk menghitung disaat teman-temannya menggunakan kalkulator tetapi harus mengikuti mood dan jam tertentu untuk mengerjakannya. Seiring bertambahnya usia dan perkembangan Pieter, saat ini ia mampu makan dan mandi sendiri. Pieter juga sudah dapat mengontrol emosinya sendiri. Jarang untuk Pieter mengamuk dan mencakar tangan Aaron atau asisten rumah tangganya. Melihat perkembangan yang dialami Pieter membuat Aaron tidak khawatir dalam hal kemampuan dan kemandirian Pieter kelak.

Selain itu, diusia Pieter yang memasuki dewasa awal belum menunjukkan ketertarikan dengan lawan jenis. Hal ini terlihat Pieter tidak menunjukkan tanda-tanda atau sinyal tertarik dengan lawan jenis. Apabila dilihat dari tugas perkembangan remaja, tidak sesuai dengan perkembangan remaja yang sudah mulai mengalami ketertarikan dengan lawan jenis dan hubungan dengan orang lain. Fase ini dapat menjadi faktor risiko bagi Aaron disebabkan belum terpenuhinya kebutuhan minat seksualitas yang dimiliki Pieter. Selain itu, Pieter juga tidak dapat menentukan identitasnya sendiri, serta mempersiapkan karir ekonomi dan masa depan. Hal ini terlihat hingga saat ini ia masih berada dalam pengawasan dan kontrol yang kuat dari Aaron. Selain itu, Aaron belum dapat melihat potensi atau kemampuan yang sangat menonjol dari Pieter. Aaron mencoba memfasilitasi dan mengenalkan Pieter melalui kesenian tetapi minat yang ditunjukan Pieter hanya sementara.

Aaron dan istri menjadi pengasuh utama yang mengurus dan mengasuh Pieter. Hingga akhirnya mereka menemukan pola untuk mengasuh Pieter. Saat ini Aaron hanya melanjutkan apa yang sudah ia dan istrinya lakukan selama ini kepada Pieter. Ketika Pieter berumur 15 tahun, istri Aaron mengalami sakit yang menyerang autoimunnya. Aaron membawa istrinya ke Singapore untuk melakukan pemeriksaan. Setelah mendapat diagnosa tersebut, istri Aaron harus rutin meminum obat. Seiring berjalannya waktu, berat badan istri Aaron turun drastis, dan obat-obatan yang dikonsumsinya menyerang ginjal istri Aaron. Lima tahun kemudian, istri Aaron meninggal dan menjadikan Aaron sebagai ayah tunggal. Ketika ia menjadi ayah tunggal, ia sempat merasa berat untuk mengurus ketiga anaknya. Hal yang dimaksud adalah Aaron mengetahui perannya sebagai tulang punggung keluarga. Disatu sisi, ia berpikir bahwa ia bekerja untuk memenuhi kebutuhan keluarganya tetapi ia juga harus mengurus anak-anaknya sehingga waktu merupakan hal yang penting baginya. Aaron harus mengatur waktu bekerja dengan antar jemput kedua anaknya. Anak ke dua Aaron sedang sekolah di luar negeri sehingga Aaron hanya mengantar jemput Pieter dan Grace ke sekolah atau tempat les yang berbeda dalam satu waktu. Walaupun Aaron seorang wirausaha dan lebih banyak bekerja di rumah namun, perlu menyesuaikan diri dalam mengatur jadwal anak-anak.

Selain itu, Aaron terkadang harus menunda urusan pekerjaannya atau jika ingin bertemu dengan teman atau klien, harus menyesuaikan waktu agar tidak menganggu antar jemput Pieter atau Grace.

“...setelah gaada maminya ya memang sih gitu ada sedikit berat karna ya itu hm urusan pekerjaan itu kadang saya ditunda, dikesampingkan dulu, di mana saya harus jemput Pieter atau mungkin kadang kalo saya mau janjian sama orang saya musti setting waktu bisa janjian ketemuan sama saya itu di bawah jam 3 (tiga) atau di atas jam 5 (lima) sore yang di mana jam 3 (tiga) perjalanan saya jemput Pieter itu hm kurang lebih 2 (dua) jam pulang pergi, jadi pergi dari rumah jam 3 (tiga) bisa tiba di 
rumah jam 5 (lima), jam 5 (lima) sekianlah gitu. Jadi dengan berjalannya waktu kayaknya sudah terprogram semua gitu jadi udah gaada masalah sih"

Seiring dengan berjalannya waktu sebagai ayah tunggal, Aaron mulai terbiasa dan menerima dirinya menjalankan dua peran sebagai ayah dan ibu dalam satu waktu hingga ia tidak menganggap ini adalah sebuah tantangan atau masalah yang harus dihadapi. Aaron merasa bahwa dirinya mempunyai tanggung jawab untuk mengurus anak-anaknya dan dengan keyakinan yang dimiliki membuat Aaron merasa lebih kuat dan tidak menganggap ini sebagai sebuah beban. Selain itu, keterlibatan Aaron dalam mengurus dan mengasuh anak sejak anak dini membuat ia terbiasa dan bukan sesuatu hal yang baru bagi Aaron.

Selain itu, Aaron berada dalam lingkungan yang mendukung dan peduli terhadap dirinya dan Pieter. Ia tidak mendapat tekanan dari lingkungan mengenai kondisi Pieter baik lingkungan rumah, sekolah, maupun rekan kerja. Aaron memiliki kemampuan dalam bersosialisasi dan menjalin hubungan baik dengan lingkungan sekitarnya. Aaron memiliki komunitas gereja yang sudah berteman bertahuntahun ketika anak-anaknya masih kecil hingga saat ini. Salah satu dukungan yang diberikan oleh teman-temannya adalah tidak menerima alasan apabila Aaron tidak dapat ikut berlibur karena tidak ada yang mengurus makanan untuk Pieter. Maka dari itu, dukungan yang diberikan dengan memperhatikan jam makan dan mengurus makanan Pieter selama berlibur.

Aaron menganggap bahwa kehadiran teman-teman dan komunitas gereja cukup penting bagi dirinya sehingga dapat dikatakan sebagai faktor protektif Aaron. Selain menunjukkan kepedulian, hal ini dapat memberi manfaat satu sama lain dengan bertukar informasi mengenai apa saja terutama mengenai dokter atau obat-obatan ketika Pieter sakit. Karakteristik internal yang dimiliki oleh Aaron adalah melihat perkembangan yang dialami Pieter saat ini membuat ia memiliki harapan bahwa Pieter dapat mandiri suatu hari nanti sehingga mendorong Aaron untuk memberikan terapi dan mengajarkan kemandirian kepada Pieter.

Secara spiritualitas, Aaron memiliki kedekatan dengan Tuhan dan berserah sepenuhnya, serta percaya bahwa apa yang terjadi dalam hidupnya adalah kehendak Tuhan. Hal ini yang membuat Aaron lebih optimis dalam menjalankan kesehariannya. Selain berserah, Aaron juga meminta kepada Tuhan untuk pemulihan diri agar dapat menerima kondisi tersebut.

Karakteristik internal yang paling menonjol dari Aaron adalah kedekatannya dengan Tuhan hal ini disebabkan interaksi yang terlihat adalah active coping yang dilakukan oleh Aaron dalam menghadapi stresor. Ketika Aaron mulai merasa stres hal yang dilakukan adalah berdoa kepada Tuhan. Hal ini dilakukan karena ia merasa hal yang membuat ia tenang adalah ketika ia berdoa dan menyerahkan semua beban pikirannya kepada Tuhan. Kemudian, melalui keyakinannya membuat Aaron mempunyai pemikiran yang lebih positif untuk mengurangi tantangan atau konsekuensi dari tantangan yang dihadapi atau disebut cognitive reframing. Ia berpikir bahwa orangtua bertanggung jawab atas anak yang diberikan oleh Tuhan dan anak tidak dapat memilih ia mau dilahirkan atau tidak dan dalam kondisi seperti apa.

Selain itu, Aaron memiliki kepercayaan terhadap keunikan dirinya sendiri. Walaupun ia tidak mampu untuk membandingkan antara dirinya dengan ayah tunggal lainnya namun, ia merasa bahwa dirinya adalah seorang yang bertanggung jawab sebagai seorang ayah dan memiliki kepedulian terhadap anak-anaknya. Ia selalu ingin memberikan yang terbaik untuk Pieter dengan memperhatikan hal-hal yang menjadi kebutuhan Pieter. Selain itu, adanya internal locus of control yang dimiliki Aaron dalam mengambil keputusan, terutama dalam mengurus dan mengasuh Pieter. Setiap pengambilan keputusan berada dalam keputusan Aaron secara penuh. Sangat jarang untuk meminta pendapat atau saran dari keluarga atau kerabat. Aaron juga menunjukkan kemandirian dirinya dalam keterlibatannya mengurus Pieter.

INSAN Jurnal Psikologi dan Kesehatan Mental

2021, Vol. 6(1), 22-43

doi: 10.20473/jpkm.v6i12021.22-42 
Kemampuan kognitif yang dimiliki Aaron adalah mampu mengatur waktu antara urusan pekerjaan dengan mengasuh Pieter dan Grace tanpa menghalangi kemampuan kerja yang dimilikinya. Aaron juga mencari tahu kemampuan yang dimiliki Pieter dengan melihat dari kesukaan Pieter terhadap musik. Ia mencoba mengenalkan Pieter kepada alat musik keyboard dan drum dengan harapan Pieter mampu memainkan alat musik. Hal ini dilakukan karena Aaron melihat bahwa Pieter suka mendengarkan lagu sehingga Aaron memperkenalkannya dengan alat musik. Sayangnya hal tersebut tidak berlangsung lama. Sekarang Pieter tidak mau memainkan alat musik tersebut. Kemudian, Aaron mencoba membelikan komputer dengan harapan dapat memudahkan Pieter dalam melakukan sesuatu dengan digital. Hingga saat ini Pieter menggunakan gadget untuk bermain games atau nonton youtube. Aaron memiliki kemampuan reflektif intrapersonal dalam memandang dirinya sebagai seorang ayah. Ia merasa bahwa dirinya adalah seseorang yang bertanggung jawab sebagai seorang ayah. Kemudian, Aaron mampu melihat konsekuensi dari setiap pilihan yang diambil. Ia tidak mau memaksakan kehendaknya terhadap masa depan Pieter.

Aaron memiliki kemampuan empati dan sosial interpersonal yang baik. kemampuan sosial tersebut ditunjukkan dengan keterbukaan dan kemudahannya dalam bersosialisasi dengan saudara dan teman. Aaron bergabung dalam sebuah komunitas gereja. Ia sudah berteman sejak anak-anaknya masih kecil hingga saat ini. Hal ini menunjukkan bahwa hubungan pertemanan berjalan dengan baik hingga bertahun-tahun dan saling mendukung satu sama lain. Kondisi yang dialami Aaron tidak memengaruhi hubungannya dengan lingkungan. Keterbukaan dalam pertemanan membuat Aaron tidak merasa kesepian dan dapat menghabiskan waktu bersama. Selain itu, ia dapat mengungkapkan emosi positif maupun negatif yang dirasakan kepada teman-temannya sehingga ia dapat merasa lebih tenang.

Stabilitas dan manajemen emosional dapat ditunjukkan dengan kemampuan individu dalam mengatur emosinya (Kumpfer, 1999). Aaron mampu mengenali ketika dirinya sedang merasakan perasaan yang negatif dan mampu untuk mengolah perasaan tersebut ketika bertemu dengan Pieter. Aaron tidak pernah mencampurkan masalah pribadi atau pekerjaan dengan anak-anaknya, serta tidak melampiaskan perasaan negatif tersebut kepada anak-anaknya.

Selain mampu mengolah perasaannya sendiri, ia juga mampu mengontrol perasaan Pieter ketika sedang marah. Hal yang dilakukan adalah menanyakan apa yang dirasakan dan diingini Pieter atau terkadang jika Pieter sudah tidak dapat dikendalikan, Aaron menggertak Pieter menggunakan penggaris tetapi Aaron tidak pernah menggunakan kekerasan fisik untuk mendidik anak-anaknya.

Aaron juga suka melontarkan candaan dengan Pieter. Aktivitas bersama yang biasa dilakukan adalah bercanda dengan Pieter dan adik-adiknya. Hal tersebut yang membuat mereka melakukan interaksi setiap hari. Aaron sangat menjaga kesehatan fisiknya dengan rutin berolahraga, yaitu bermain badminton dan minum jamu agar dapat menjaga staminanya tetap sehat. Hal ini juga didukung oleh partisipan triangulasi yang mengatakan bahwa Aaron menjaga kesehatannya dengan rutin berolahraga, yaitu berenang dan tidak ada keluhan atau gejala-gejala yang ditunjukkan. Selain menjaga fisiknya agar tetap sehat, aktivitas secara fisik yang dilakukan Aaron bersama Pieter selain berenang setiap sore adalah menghabiskan waktu bersama dengan bercanda. Ketika ada waktu lenggang, Aaron akan mendekati Pieter dan melontarkan candaan. Hal ini juga sesuai dengan pernyataan yang diberikan oleh asisten rumah tangga Aaron.

Selective perception yang digunakan Aaron adalah ketika mendapat desakan untuk menikah kembali. Desakan tersebut tidak langsung diterima oleh Aaron. Hal ini menjadi sebuah pertimbangan bagi Aaron, di sisi lain ia memikirkan anaknya yang ketiga masih kecil dan membutuhkan sosok ibu dalam hidupnya namun, ia juga memikirkan kondisi Pieter dapat diterima atau tidak oleh pasangan barunya. 
Aaron merasa dirinya dapat menerima dan mulai menjalankan peran ganda, yaitu sebagai ibu dan ayah seiring dengan berjalannya waktu. Hal tersebut sudah menjadi sebuah kebiasaan yang dijalani sehari-hari. Ia mengakui bahwa pada awalnya memang tidak mudah tapi seiring dengan berjalannya waktu, ia mulai terbiasa dan tidak menjadikan hal tersebut sebagai beban.

Hal yang membuat Aaron bertahan menjadi seorang ayah tunggal dan mengurus remaja autisme adalah ia menyadari bahwa seorang anak tidak dapat memilih untuk dilahirkan atau tidak dan dalam keadaan seperti apa. Melalui artikel-artikel yang dibaca, ia dapat mengambil pelajaran dan mengubah pandangannya mengenai apa yang terjadi dalam hidupnya. Aaron berpikir bahwa anak adalah titipan dari Tuhan sehingga membuat Aaron belajar untuk bersyukur dengan keadaan yang dialami saat ini. Ia masih dapat bersyukur mengenai Tuhan selalu mencukupi Aaron untuk merawat anak-anaknya. Ia tidak pernah malu untuk mengakui bahwa anak pertamanya mengalami gangguan autisme.

Aaron menyadari bahwa anak autisme membutuhkan kasih sayang dari lingkungannya. Maka dari itu, Aaron ingin memberikan kasih sayang tersebut dalam keseharian Pieter. Pieter juga mengerti jika Aaron menyuruhnya untuk peluk atau cium Aaron atau adik-adiknya. Penerimaan yang dilakukan Aaron kepada Pieter membuat hal tersebut tidak menjadi beban dalam kesehariannya hingga saat ini. Bahkan ketika istri Aaron meninggal, ia tidak mengalami kesulitan karena ia terbiasa untuk menyayangi dan mengasuh Pieter dari kecil hingga sekarang. Aaron mengakui bahwa awalnya tidak mudah ketika istrinya meninggal. Hal ini disebabkan ia harus adaptasi dengan peran yang ia jalani. Setelah istri Aaron meninggal, ia banyak merelakan urusan pekerjaan untuk menghabiskan waktu bersama Pieter.

Individu resilien adalah individu yang memiliki karakteristik internal dan lingkungan eksternal yang mendukung sehingga mampu menjadi individu yang lebih baik dan berhasil melakukan adaptasi meskipun dihadapi dengan berbagai tantangan (Schaefer \& Moos, dalam Glantz \& Johnson, 2002). Ayah yang memiliki adaptasi sukses dapat dihat dari penerimaan terhadap kondisi anaknya dan ketika kehilangan istrinya, mampu menyeimbangkan tuntutan pekerjaan dengan mengasuh anak autisme, serta dapat menarik insight sebagai ayah tunggal.

Hasil adaptasi Aaron dilihat dari ketika ia menyeimbangkan tuntutan pekerjaan dengan mengasuh Pieter. Apabila terdapat pilihan tuntutan pekerjaan yang mengharuskan Aaron keluar kota, ia memilih untuk pergi di hari Kamis atau Jumat. Hal ini disebabkan ia menyesuaikan jadwal libur Pieter. Jika mengharuskan Aaron pergi selama empat hari dengan terpaksa Pieter izin sekolah.

Aaron juga dapat menarik hikmah atau insight dari dirinya sebagai ayah tunggal yang memilik anak autisme, yaitu ia dapat menerima kondisi Pieter jauh sebelum istrinya meninggal sehingga ketika istrinya meninggal ia tetap dapat menerima dan tidak menganggap Pieter adalah sebuah beban bagi dirinya. Bahkan ia menyadari bahwa Pieter adalah sebuah tanggung jawab. Ia menyadari peran orangtua yang bertanggung jawab untuk mengasuh anak-anaknya. Proses resiliensi yang dialami oleh Aaron terjadi ketika Aaron menerima diagnosa Pieter yang mengalami gangguan autisme sehingga ketika istri sakit, sudah ada antisipasi grief yang dilakukan Aaron saat istri meninggal. Hal ini dapat membantu atau mempercepat proses resiliensi Aaron.

Hasil lainnya adalah ketika ditanya mengenai perasaan Aaron setelah berbagi cerita tentang kondisinya, ia pun merasa senang bisa berbagi cerita dengan orang lain dan memiliki harapan untuk ayah yang memiliki anak autisme untuk tidak menjauhkan dirinya dengan anak tersebut.

\section{Partisipan 2}

Mikael dikaruniai tiga orang anak, yaitu Gabriel (24 tahun), Rachel (22 tahun), dan Barry (18 tahun). Anak pertama dan kedua Mikael regular tetapi anak ke tiga Mikael memiliki gangguan autisme ringan. INSAN Jurnal Psikologi dan Kesehatan Mental 2021, Vol. 6(1), 22-43

doi: 10.20473/jpkm.v6i12021.22-42 
Pada awalnya Mikael dan istri tidak menyadari gejala-gejala yang dialami Barry. Ketika lahir Barry telah memiliki gigi dan sering jatuh dari tempat yang tinggi. Barry dikenal sangat hyperactive ketika masih kecil tetapi mereka berpikir bahwa hal tersebut adalah hal yang biasa sebagai anak kecil yang masih terus berkembang. Sejak kecil telinga Barry sering mengeluarkan cairan dan Barry belum dapat berbicara hingga akhirnya kedua orangtua membawa Barry ke dokter THT.

Ketika diperiksa oleh dokter THT, Barry tidak bisa diam dan terus memberontak ketika ingin dipegang oleh dokter. Ketika dokter berhasil untuk memeriksa Barry, dokter tersebut mengatakan memang terdapat masalah dari telinga Barry dan terdapat gejala lain yang dialami Barry. Dokter meminta Mikael dan istri memeriksa ke psikolog. Hal ini disebabkan dokter curiga hyperactive dan keterlambatan bicara Barry merupakan gejala autisme ringan.

Mikael dan istri tidak memiliki kecurigaan apapun terhadap keterlambatan Barry dalam berbicara dan hyperactive Barry hingga kecurigaan tersebut muncul ketika membawa Barry ke dokter THT. Mendengar kecurigaan dokter THT dan saran yang diberikan untuk memeriksa Barry lebih lanjut membuat istri Mikael mencari tahu gejala-gejala autisme melalui buku, internet, dan bertanya kepada saudara dan teman. Keterbatasan biaya yang dimiliki Mikael dan istri membuat mereka tidak membawa dan melakukan pemeriksaan lebih lanjut kepada Barry. Mereka mulai mencari tahu mengenai anak dengan gangguan autisme dan memperhatikan perkembangan Barry.

Seiring dengan berjalannya waktu berdasarkan kecurigaan dokter THT dan pengetahuan yang diketahui Mikael dan istri membuat mereka berpikir penyebab Barry mengalami gangguan autisme ringan. Mereka merefleksikan kesalahan yang telah mereka perbuat hingga mereka memiliki anak dengan gangguan autisme ringan. Perasaan sedih dan bertanya-tanya dialami oleh Mikael dan istri.

Selain itu, istri Mikael juga mengira bahwa penyebab Barry mengalami gangguan tersebut disebabkan seringnya Barry terjatuh sehingga ada bagian syaraf tertentu yang terjepit. Gejala lainnya yang baru disadari ketika Barry lahir sudah memiliki gigi. Hal tersebut mungkin merupakan salah satu tanda yang muncul. Tidak membawa Barry untuk melakukan pemeriksaan lebih lanjut membuat mereka tidak mendapat diagnosa yang benar-benar akurat. Mereka hanya mencari tahu dan memberikan diagnosa sendiri terhadap Barry. Istri Mikael mengatakan bahwa Barry mengalami PDD-NOS, sedangkan Mikael mengatakan bahwa Barry mengalami gangguan autisme ringan. Setelah mengetahui kondisi Barry tidak membuat mereka tidak menerima kondisi Barry, justru sebaliknya mereka tetap mengucap syukur dengan kondisi Barry dan tetap merawat Barry, serta mengetahui perkembangannya dari kecil hingga saat ini.

Lulus dari taman kanak-kanak, Mikael ingin memasukkan Barry di sekolah dasar regular. Hal ini disebabkan keterbatasan biaya yang dimiliki apabila Barry masuk Sekolah Luar Biasa (SLB) atau sekolah khusus lainnya. Mereka mendatangi sekolah-sekolah regular tetapi mereka tidak dapat menerima Barry disebabkan gangguan yang dimiliki Barry. Mikael mencoba untuk mendatangi salah satu SLB dan melakukan konsultasi. Pihak sekolah menerima Barry agar ia dapat bersekolah disana. Barry akan satu kelas dengan anak-anak yang memiliki gangguan yang sama. Melihat kondisi kelas dan anak-anak di sekolah tersebut membuat Mikael tidak ingin memasukkan Barry karena ia merasa bahwa Barry tidak separah dan tidak seperti anak-anak yang ada di kelas tersebut. Ia khawatir apabila Barry disana akan sama seperti anak-anak disana atau mungkin mereka dapat melukai Barry.

Akhirnya Mikael meminta saran dan konsultasi dengan saudara-saudaranya, mereka menyarankan untuk memasukkan Barry ke sekolah terapi. Kesulitan Mikael dalam mencari sekolah dasar untuk Barry dapat menimbulkan faktor risiko. Hal ini disebabkan Mikael memiliki hambatan dalam menemukan kenyamanan untuk memberikan pendidikan kepada Barry. Terlihat ketika tidak ada sekolah regular yang bersedia menerima Barry, kemudian Mikael mencoba untuk mencari sekolah luar biasa tetapi kondisi dan perilaku anak-anak disana dirasa tidak memberikan kenyamanan dan

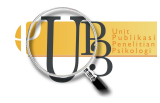


tidak mendukung untuk perkembangan Mikael. Kemudian, Mikael konsultasi dengan saudarasaudaranya dan pada akhirnya memutuskan untuk memasukkan Barry di sekolah terapi. Sekolah terapi merupakan bentuk penghindaran yang dilakukan Mikael karena Barry tidak dapat bersekolah di regular atau sekolah luar biasa sehingga hal ini berdampak bahwa Barry tidak dapat sekolah. Setelah menjalani terapi hingga umur 14 tahun, Barry tidak mengikuti terapi lainnya dan saat ini ia hanya di rumah dan diajarkan mengenai kemandirian oleh Mikael. Tugas utama dalam memberikan pendidikan adalah sekolah sehingga saat ini faktor risiko tersebut masih ada karena Mikael tidak dapat memberikan kenyamanan dalam memberikan fasilitas pendidikan kepada Barry.

Mikael menganggap bahwa apa yang dialami saat ini merupakan tantangan keluarga. Ia menyadari dirinya dan istri memiliki peran sebagai orangtua sehingga apapun kondisi yang dialami Barry, mereka memiliki tanggung jawab terhadap Barry. Hal ini membuat Mikael dan istri mengasuh Barry dengan sepenuh hati dan tidak menganggap beban, serta mereka tidak menitipkan atau meminta bantuan dari orang lain untuk mengasuh Barry.

Di sisi lain, istri Mikael memiliki penyakit turunan, yaitu asma dan paru-paru basah. Ketika memiliki anak pertama dan kedua, asma istri Mikael tidak begitu parah namun, mulai terlihat ketika istri Mikael melahirkan anak ketiga. Kondisi Barry membuat istri Mikael harus memberikan usaha dan tenaga lebih dalam mengasuh dan merawat Barry sehingga memengaruhi kesehatannya. Seiring berjalannya waktu istri Mikael mengalami penurunan secara fisik ketika tahun 2012 sehingga harus melakukan pemeriksaan rutin di rumah sakit. Pada tahun 2014, istri Mikael sempat dirawat di rumah sakit selama 2 minggu dan pulang ke rumah selama 2 minggu kemudian meninggal. Proses resiliensi yang dialami oleh Mikael terjadi ketika Mikael menerima diagnosa Barry yang mengalami gangguan autisme sehingga ketika istri sakit, sudah terdapat antisipasi grief yang dilakukan Mikael saat istri meninggal. Hal ini dapat membantu atau mempercepat proses resiliensi Mikael.

Setelah istri meninggal, Mikael yang mengurus Barry 100 persen. Ia mulai mengerti dan merasakan bagaimana orangtua mengasuh anak yang memiliki gangguan autis ringan sendirian. Hal ini yang menjadi tantangan bagi Mikael. Mikael sempat bingung bagaimana ia membagi waktu antara mengasuh Barry dengan harus tetap bekerja untuk memenuhi kebutuhan keluarga. Pada saat itu anak pertama dan kedua Mikael bekerja dan kuliah. Ia khawatir apabila ia bekerja, tidak ada yang mengurus Barry. Mikael sempat memutuskan bekerja namun, berhenti setelah satu tahun dan saat ini hanya freelance.

Kebingungan yang dialami Mikael terkadang membuat emosionalnya tidak stabil sehingga ia kehilangan kesabarannya ketika melihat tingkah laku Barry tetapi ia tahu bahwa Barry tidak mengerti apa-apa sehingga ia yang harus mengontrol emosinya sendiri.

Mikael melatih dan mengajarkan kemandirian Barry, seperti makan, mandi sendiri. Mikael juga mengajarkan aktivitas agar Barry memiliki rutinitas dan mengetahui kapan ia harus makan, kapan ia harus mandi dan apa saja yang dilakukan. Ia mengajari Mikael dimana ia harus membuka baju dan dimana ia harus mengambil baju setelah mandi. Mikael mengetahui bahwa anak dengan gangguan autis ringan memiliki memori untuk merekam rutinitas yang diajarkan. Mikael menyadari bahwa terdapat perbedaan ketika istri Mikael yang mengasuh Barry dengan Mikael yang mengurus Barry saat ini. Ketika istrinya masih hidup, ia sedikit memanjakan Barry tetapi setelah istri Mikael meninggal, Mikael lebih mengajarkan kemandirian sesuai dengan perkembangan Barry.

Saat ini, hal yang dapat dilakukan oleh Barry adalah ia mampu untuk makan, mandi, gosok gigi sendiri, menggambar, dan apabila ditinggal di rumah sendirian, Barry paham bahwa ia tidak boleh melakukan hal-hal yang berbahaya, seperti berada di dapur, memainkan kompor, keluar rumah. Ia juga paham apabila diberitahu makanan yang disiapkan untuk dimakan pada pagi dan siang hari. Ketika Mikael pulang, ia juga mengetahui dan membuka pintu untuk Mikael. Ia juga sering menanyakan kapan

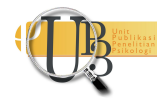


kakaknya pulang dan menunggu pulang. Di sisi lain, diusia Barry yang merupakan remaja belum menunjukkan ketertarikan dengan lawan jenis. Hal ini tidak sesuai dengan perkembangan remaja lainnya yang mulai mengalami ketertarikan dengan lawan jenis dan hubungan dengan orang lain. Fase ini dapat menjadi faktor risiko bagi Mikael disebabkan belum terpenuhinya kebutuhan minat seksualitas yang dimiliki Pieter. Apabila dilihat dari tugas perkembangan remaja, masa remaja mulai membangun hubungan yang lebih matang dengan orang lain dan tidak hanya terpusat pada diri sendiri namun, hal ini belum terlihat dari Barry. Ia masih terlihat individual dan tidak memiliki minat terhadap hubungan sosial atau interaksi sosial. Selain itu, remaja mulai menentukan identitas, karir ekonomi dan masa depan namun, Barry belum menunjukkan hal tersebut. Hal ini terlihat, pengawasan dan kontrol yang kuat masih dipegang oleh Mikael. Belum terlihat minat yang dimiliki Barry untuk menunjang masa depannya.

Titik terberat yang dialami Mikael adalah saat ia harus melepas pekerjaannya untuk mengasuh Barry. Ketika Barry masih bekerja, ada perasaan tidak tenang untuk meninggalkan Barry sendiri sehingga Mikael tidak fokus terhadap pekerjaannya. Di satu sisi, sulit bagi Mikael untuk melepaskan pekerjaanya karena ia tahu bahwa ia adalah tulang punggung keluarga yang harus memenuhi kebutuhan keluarga. Mikael menyadari tanggung jawabnya sebagai kepala keluarga yang mencari nafkah untuk memenuhi kebutuhan keluarga. Mikael masih harus memenuhi kebutuhannya dan Barry. Maka dari itu, ia harus tetap bekerja tetapi di sisi lain, Barry tidak memiliki caregiver yang dapat membantu Mikael dalam mengasuh disebabkan kakak kedua Barry sebagai caregivernya sudah menikah dan baru saja melahirkan sehingga untuk sementara waktu ia harus tinggal di rumah mertuanya. Hal ini membuat Mikael sebagai satu-satunya orang yang dapat menjaga dan mengasuh Barry. Kondisi tersebut membuat Mikael harus menyeimbangkan antara bekerja dengan mengasuh Barry. Hal ini dapat menjadi faktor risiko bagi Mikael disebabkan kehilangan dua caregiver yang dapat membantu mengurus Barry.

Selain itu, sosial ekonomi sedang yang dimiliki Mikael. Ia tidak dapat memprioritaskan untuk membayar asisten rumah tangga dalam membantunya menjaga Barry. Hal ini membuat Mikael kesulitan dalam mempertahankan pekerjaan di hotel dan mencari pekerjaan yang baru. Di sisi lain, Mikael senang bersosialisasi dan sangat terbuka dengan keluarga dan teman-teman maupun orang yang baru dikenal. Mikael tidak malu untuk mengakui dan menceritakan kondisi anak bungsunya. Ia memiliki hubungan yang baik dengan keluarga dan teman-teman. Mikael merasa tidak terbeban dengan lingkungan eksternalnya. Teman-teman Mikael justru memberikan dukungan dan menerima kondisi Mikael memiliki anak autisme. Penerimaan tersebut terlihat ketika ada acara reuni mereka akan menyuruh Mikael untuk membawa Barry dan selalu menanyakan kabar Barry apabila Barry tidak diajak.

Ketika mengalami tekanan, active coping yang dilakukan Mikael adalah bertemu dan bercerita dengan teman lamanya. Ia merasa bahwa dengan bercerita rasa beban yang dirasakan sedikit berkurang. Terkadang ia tidak membutuhkan saran tetapi hanya butuh ada seseorang yang mendengar keluhkesahnya. Mikael juga lebih memilih untuk bercerita kepada teman-temannya dibanding ke saudara karena saudara juga sudah sibuk untuk bekerja dan mengurus keluarganya masing-masing. Sampai saat ini setiap Mikael bercerita kepada teman-temannya pasti akan direspon dan diberikan saran untuk Mikael terutama mengenai Barry. Selain bercerita kepada teman, Mikael juga memilih untuk ke gereja atau ketika di rumah, ia akan masuk kamar dan berdoa kepada Tuhan.

Salah satu tekanan yang dialami Mikael sebagai ayah tunggal adalah harus mencari teman atau seseorang untuk bercerita, jika masih memiliki istri maka istrilah yang menjadi teman untuk bisa berdiskusi dan sharing satu sama lain. Penerimaan yang dilakukan keluarga terlihat saat kumpul keluarga mereka akan menanyakan keadaan Barry. Keluarga pasti akan mengutamakan Barry dan selalu ingin ada Barry disetiap pertemuan keluarga. Keluarga juga memberikan saran kepada Mikael

INSAN Jurnal Psikologi dan Kesehatan Mental

2021, Vol. 6(1), 22-43

doi: 10.20473/jpkm.v6i12021.22-42

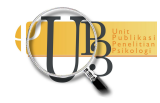


agar tidak memarahi Barry dan memberikan rasa sayang yang terus menerus kepada Barry. Selain itu, dukungan yang diberikan berupa saran-saran yang diterima membuat Mikael termotivasi dan sangat membantu dalam mengasuh Barry. Salah satu aktivitas yang disarankan adalah melakukan aktivitas fisik, seperti olahraga.

Bagi Mikael, keluarga dan teman-teman menjadi faktor protektif. Penerimaan dan dukungan yang diberikan sangat memengaruhi Mikael untuk lebih termotivasi dalam mengasuh Barry. Ia merasa bahwa keluarga dan teman-teman merupakan tempat bercerita dan sharing satu sama lain. Menurut Mikael saran yang diberikan sangat positif, tidak hanya baik untuk perkembangan Barry tetapi dapat mengembangkan Mikael dalam mengasuh Barry.

Selain keluarga dan teman-teman Mikael, hubungan antara Barry dengan kedua kakaknya memiliki hubungan yang baik. Hal ini menjadi faktor protektif bagi Barry. Kedua kakaknya sangat sayang kepada Barry dan memberikan perhatian penuh. Sejak kecil kakak pertama Barry sering bermain dengan Barry dan Rachel suka memperhatikan Barry ketika sedang bermain dan memperhatikan apa yang menjadi kebutuhan Barry. Kakak kedua Barry lebih dekat dengan Barry karena lebih banyak waktu bertemu dibanding kakak pertama Barry.

Kedekatan Barry dengan keluarga juga terlihat ketika Mikael masih bekerja di luar kota dan hanya pulang dua minggu sekali atau sebulan sekali. Hal ini tidak membuat Barry lupa dengan Mikael. Ketika Mikael pulang ke rumah, Barry akan terus berada didekat Mikael. Hal ini disebabkan Mikael selalu meluangkan waktu untuk Barry ketika berada di rumah dan sering mengajak Barry untuk melakukan aktivitas berdua yang sederhana, seperti potong rambut, membeli gorengan atau ke warung.

Saran yang diberikan oleh lingkungan eksternal Mikael memiliki peran sebesar 40 persen ketika Mikael ingin mengambil keputusan yang berhubungan dengan Barry. Tidak semua masukkan diterima oleh Mikael, saran yang diterima akan dijadikan bahan pertimbangan kemudian ia yang akan memutuskan tindakan yang akan diambil karena ia merasa dirinya yang lebih memahami dan mengetahui kondisi Barry.

Salah satu saran yang diberikan teman Mikael adalah mengajarkan Barry untuk mandiri dengan cara meninggalkan Barry di rumah sendiri. Teman Mikael memberikan saran tersebut karena ia melihat bahwa Barry memiliki autis ringan dan ia tidak merusak atau banyak melakukan aktivitas fisik, ia hanya akan duduk dan menonton youtube menggunakan gadgetnya. Hal tersebut membuat teman Mikael berpikir bahwa Barry dapat ditinggal sendiri di rumah dan diajarkan untuk tidak keluar rumah atau melakukan aktivitas yang membahayakan, seperti menyalakan kompor. Ia kasian kepada Barry apabila Barry selalu ikut Mikael bekerja, Barry hanya akan merasa lelah setiap harinya. Mendengar saran tersebut menjadikan bahan pertimbangan bagi Mikael dan ia mencoba untuk melakukan hal tersebut. Walaupun pada awalnya ia khawatir meninggalkan Barry untuk pertama kalinya sendiri di rumah tetapi lama kelamaan Mikael terbiasa dan Barry sudah mengerti apa saja yang harus ia lakukan selama di rumah.

Mikael memiliki semangat dan kesabaran yang tinggi dalam menjalani kondisi yang dialami. Bagi Mikael, kondisi yang dialaminya tidak menjadikannya sebuah beban. Hanya saja ia harus membagi waktu antara bekerja dengan mengasuh Barry. Hal yang dipikirkan Mikael adalah karena ia belum memiliki pekerjaan yang stabil untuk memenuhi kebutuhan keluarga tetapi ia juga harus menjaga dan mengasuh Barry. Pengharapan yang dimiliki Mikael untuk perubahan di masa yang akan datang membuat ia lebih memandang apa yang dapat ia jalani saat ini dan lebih fokus tanpa mengeluh.

Secara spiritualitas, Mikael berserah sepenuhnya kepada Tuhan apa yang dialami. Ketika ia sedang merasa tertekan atau dalam keadaan yang tidak baik, ia memilih untuk masuk kamar dan berdoa 
kepada Tuhan. Hal ini membantunya untuk lebih tenang dan lebih mempercayakan apa yang terjadi kepada Tuhan.

Walaupun ada pengaruh dari orang lain sebagai bahan pertimbangan dalam mengambil keputusan tetapi Mikael memiliki internal locus of control untuk menentukan keputusan terakhirnya. Tidak semua saran atau pendapat orang lain diterima langsung oleh Mikael. Mikael memiliki harapan bagi Barry dan kedua anaknya. Ia ingin agar Barry dapat sembuh dan terus berkembang seiring berjalannya umur. Ia menyadari bahwa Barry memerlukan terapi kemandirian dengan mengajarkan dan memberikan rutinitas setiap hari agar ia memiliki perkembangan.

Selain itu, harapan Mikael kepada kedua anaknya agar dapat mengurus Barry ketika ia sudah tidak ada. Mikael khawatir siapa yang akan mengurus Barry nantinya, maka dari itu ia mulai mendekatkan diri kepada anak keduanya, yaitu Rachel agar mau mengasuh Barry ketika Mikael sudah tidak ada. Hal ini disebabkan Mikael melihat bahwa Rachel lebih perhatian kepada Barry dan dapat diandalkan. Mikael khawatir apabila yang merawat kakak pertama Barry, ia takut jika Gabriel berkeluarga, keluarga dari istri Gabriel tidak dapat menerima Barry.

Mikael menyadari kemampuan yang dimiliki Barry sejak ia kecil. Saat Barry masih di sekolah terapi, ia melihat bahwa Barry suka menggambar sehingga bagi Mikael tidak cukup apabila menggambar hanya di sekolah terapi saja, maka dari itu Mikael memberikan les melukis kepada Barry. Seiring dengan berjalannya waktu, Mikael mulai melihat ada ketidaktertarikan atau berkurangnya minat Barry terhadap melukis karena itu Mikael memberhentikan les Barry. Beberapa bulan terakhir ini, Mikael memberikan handphone kepada Barry. Ia suka mendengarkan musik. Ketika ia mendengarkan musik Barry akan berperilaku seperti ia sedang bermain drum. Mikael berpikir bahwa Barry memiliki minat dimusik tetapi Mikael tidak dapat memfasilitasi alat musik drum karena harganya yang cukup mahal. Kemudian, ia berpikir apabila memungkinkan Barry dapat diajak pelayanan bersama kakak pertamanya agar dapat mengembangkan kemampuan yang dimiliki Barry.

Mikael memiliki kemampuan sosial yang baik. Ia tidak malu untuk menceritakan kondisi Barry dan sangat terbuka dengan orang baru maupun teman lama. Ia sangat senang untuk kumpul bersama teman-teman SMA. Ketika ia pindah rumah dari Bekasi ke Tangerang, ia pun mendekatkan diri kepada tetangganya. Hal ini dilakukan untuk antisipasi jika terjadi sesuatu dengan Barry di rumah, tetanggatetangganya lah yang akan pertama menjadi penolong Barry. Maka dari itu, ia mencoba mendekatkan diri kepada tetangganya.

Keterbukaan yang dilakukan Mikael terbukti ketika ia sedang bekerja freelance dan membawa penumpang, ia tidak malu menceritakan kondisi Barry dan tidak memandang teman lama atau orang yang baru dikenal. Kondisi yang dialami Mikael tidak memengaruhi hubungan Mikael dengan keluarga atau teman-temannya. Justru mereka memiliki hubungan yang baik dan saling membantu satu sama lain.

Kemampuan Mikael dalam mengelolah perasaannya terkadang tidak stabil. Hal ini sempat terjadi ketika ia memiliki masalah mengenai pekerjaan dan ketika ia di rumah, ia melihat tingkah laku Barry yang membuat dirinya kesal sehingga Mikael memukul Barry dibagian kaki. Namun, setelah kejadian tersebut Mikael menyadari bahwa Barry tidak salah dan ia tidak mengerti apa yang terjadi. Mikael tersadar, ia merasa sedih dan menyesal sudah memukul Barry.

Setelah Mikael menyesal dengan apa yang telah dilakukan, ia kembali memberikan perhatian dan kasih sayang kepada Barry dengan menyuruhnya menonton youtube atau menanyakan sudah makan atau belum atau mengajaknya keluar untuk membeli bakwan. Saat ini ia tidak pernah melakukan kekerasan fisik kembali kepada Barry. Mikael mampu mengenali emosi negatif yang dirasakan dan mampu mengontrol emosi tersebut.

INSAN Jurnal Psikologi dan Kesehatan Mental

2021, Vol. 6(1), 22-43

doi: 10.20473/jpkm.v6i12021.22-42 
Mikael memiliki kesehatan fisik yang baik dan tidak ada perubahan yang dialami. Ia merasa apabila tidak ada aktivitas yang dilakukan justru badannya akan merasa sakit. Mikael tidak suka jika ia hanya santai dan melihat ada sesuatu yang kotor. Ia akan membersihkan dan melakukan pekerjaan yang dapat ia kerjakan. Menurutnya, hal ini membantu ia memiliki aktivitas fisik, seperti pengganti olahraga. Selain itu, Mikael menjalankan setiap aktivitas dengan sukacita sehingga ia memiliki pikiran dan kondisi fisik yang baik. Perubahan kondisi fisik Mikael juga tidak dirasakan Rachel. Hanya saja semakin bertambahnya usia Mikael membuat Rachel melihat papanya sedikit capek namun, tidak ada perubahan yang drastis. Setelah istri Mikael meninggal, waktu yang diluangkan Mikael untuk Barry lebih banyak dan hal ini tidak membuat kecanggungan bagi Mikael karena Mikael sudah terbiasa mengurus Barry sejak kecil dan ia juga terbiasa untuk melayani klien saat bekerja sehingga Mikael mengerti bagaimana cara mengasuh dan melayani Barry.

Selective perception yang digunakan Mikael adalah ketika mendapat desakan untuk menikah kembali. Desakan tersebut tidak langsung diterima oleh Mikael. Hal ini menjadi sebuah pertimbangan bagi Mikael, ia mengetahui bahwa saran yang diberikan untuk membantunya dalam mengurus ketiga anaknya tetapi ia juga memikirkan kondisi Barry dapat diterima atau tidak oleh pasangan barunya. Menurut Barry, ia merasa masih mampu untuk mengurus rumah tangga dan mengasuh anak-anaknya sendiri. Ia juga merasa dirinya yang paling memahami kondisi Barry sehingga ia tidak mau seseorang mengasuh Barry selain dalam keadaan terpaksa.

Situasi yang dialami Mikael ketika mengalami tekanan adalah ketika Mikael sudah bekerja lebih dari 12 jam. Ia merasa kelelahan fisik sehingga terkadang lupa untuk membuat makanan Barry. Terkadang jam makan Barry terlambat karena Mikael belum memasak dan masih tertidur. Dalam menghadapi kondisi yang dialami Mikael, ia menggunakan cognitive reframing untuk memaknainya. Ia merasa kondisi yang dialaminya merupakan rencana Tuhan dan membuatnya lebih fokus untuk berpikir positif dan menjalankan apa yang terjadi saat ini.

Mikael merasa senang untuk peran yang dijalankan saat ini sebagai ayah dan ibu yang mengasuh anak dengan gangguan autisme. Hal ini membuat Mikael dapat mendekatkan diri kepada anak-anaknya, tidak hanya memperhatikan Barry tetapi juga memberikan perhatian kepada Gabriel dan Rachel. Mikael juga tidak memikirkan untuk menikah kembali karena ia sudah nyaman dan sangat senang untuk keadaannya saat ini, ia hanya fokus untuk mengasuh Barry dan ia khawatir jika ia menikah kembali apakah pasangannya nanti dapat menerima kondisi Barry. Ia juga tidak mau apabila ada orang lain yang menegur Barry, cukup Mikael yang menegur karena ia yang lebih memahami dan mengetahui kondisi Barry.

Mikael mulai menerima peran ganda sebagai ayah dan ibu pada tahun 2016. Ketika istri meninggal, ia masih bisa menitipkan Barry ke kakak atau temannya jika Mikael harus bekerja. Seiring berjalannya waktu, Mikael mengetahui bahwa tidak bisa Barry terus dititipkan ke orang lain, merasa tidak enak dan merepotkan orang lain sehingga pada tahun 2016 Mikael merasa dirinya harus menjadi ayah tunggal seutuhnya untuk mengasuh Barry. Perubahan perilaku yang dilakukan Mikael terhadap anakanaknya juga dirasakan oleh Rachel. Ia merasa bahwa papanya sangat berusaha untuk dapat dekat dan memberikan perhatian penuh kepada anak-anaknya.

Memasuki tahun 2018, Mikael mulai berpikir mengenai kesanggupan fisiknya. Ia khawatir siapa yang akan mengasuh dan menjaga Barry apabila ia merasa tidak kuat untuk mengurus Barry seiring bertambahnya umur. Hal yang membuat Mikael bertahan sebagai ayah tunggal hingga saat ini adalah kebiasaan dalam mengasuh Barry sejak kecil. Kebiasaan tersebut membuat Mikael mengetahui perkembangan yang dialami Barry sehingga Mikael terus ingin mengetahui kondisi Barry hingga dewasa. Mikael juga menyadari bahwa anak adalah titipan Tuhan dan mengetahui perannya sebagai 
orangtua sehingga harus menjaga dan memiliki tanggung jawab penuh untuk mengasuh dan merawat anak tersebut.

Salah satu hasil adaptasi sukses dapat dilihat dari bagaimana seorang ayah tunggal mampu menyeimbangkan tuntutan pekerjaan dengan mengasuh anak autisme. Pada saat Mikael bekerja selama 9 tahun di Tanjung Lesung tidak membuatnya lari dari tanggung jawab sebagai ayah untuk mengasuh anak-anaknya tetapi ia selalu menyempatkan diri untuk kembali ke Jakarta setiap dua minggu sekali atau maksimal satu bulan sekali. Apabila ada keadaan mendesak yang mengharuskan ia tidak dapat pulang ke Jakarta, ia akan meminta istri dan anak-anaknya untuk pergi ke Tanjung Lesung. Hal ini dilakukan karena Mikael ingin melihat perkembangan anak-anak dan ia sangat senang ketika Barry senang untuk diajak kesana. Mikael juga berpikir supaya anak-anak memiliki waktu liburan di tengah aktivitas sekolahnya dan dapat berkumpul dengan keluarga.

Selama proses yang Mikael jalankan, ia juga mampu untuk menarik insight atau hikmah mengenai dirinya sebagai ayah tunggal yang memiliki anak autisme, yaitu lebih mandiri dalam mengurus pekerjaan rumah dan dapat fokus untuk memberikan perhatian kepada anak-anak. Mikael merasa semenjak ia menjadi ayah tunggal, ia lebih dapat mendekatkan diri kepada anak-anaknya. Ketika ada waktu berkumpul di rumah, Mikael sangat mengusahakan untuk dapat berkomunikasi dan bercerita satu sama lain dengan anak-anak, sering kali ia tidak mau melihat anak-anak sibuk dengan handphonenya ketika sedang bersama.

Perubahan komunikasi yang dilakukan disebabkan tidak adanya komunikasi yang terjalin sejak dahulu. Jika ada masalah atau hambatan yang terjadi ketika Mikael bercerita kepada anak-anaknya tidak ada solusi yang diberikan. Mikael berpikir bahwa mungkin anak-anaknya juga bingung untuk memberikan solusi atau keputusan. Maka dari itu, ketika ada masalah pribadi, Mikael lebih memilih untuk tidak menceritakan ke anak-anak. Hanya saja apabila itu menyangkut pekerjaan yang diambil karena anak-anak harus tau papanya bekerja dimana dan sesuatu yang berhubungan dengan Barry. Perubahan komunikasi yang dilakukan tersebut menjadi lebih baik untuk mendekatkan diri kepada anak-anak.

Saat Mikael ditanya mengenai perasaannya setelah bercerita mengenai kondisi keluarga dan proses yang dialami, ia senang apabila ada orang yang bertanya tentang dirinya karena ia merasa tidak ada orang yang dapat diajak ngobrol. Maka dari itu, salah satu coping yang ia lakukan adalah senang untuk berbagi cerita dengan orang lain. Menurut Mikael hal ini membuat sedikit terlepas dari beban-beban yang dirasakan.

"Saya lebih seneng kalo ada orang yang nanya mengenai saya karena gini hm saya jujur saya gak ada orang yang bisa saya ajak ngobrol. Di rumah gak ada. Kayak temen pasti ini. Jadi kalo ada pertanyaan gini, perasaan saya seneng. Seneng-seneng aja diajak ngobrol kayak gini justru agak terlepas beban-beban yang ada dipikiran saya..."

\section{I S K U S I}

Pada proses resiliensi yang dilalui dua partisipan, dapat dilihat pola yang sama ketika individu mendapat stresor. Individu membutuhkan untuk dapat mengekspresikan emosi sesuai dengan kenyamanannya baik sendiri atau membutuhkan orang lain. Ketika individu sudah dapat mengekspresikan emosinya, mereka akan mulai mencari informasi mengenai anak autisme dan membutuhkan dukungan dari lingkungan sekitar. Ketika individu mengalami stresor kedua, yaitu sebagai ayah tunggal, individu tetap membutuhkan dukungan dari orang-orang disekitar untuk dapat mengekspresikan emosinya dan mencari informasi yang dibutuhkan. Kemudian, individu mulai mempertimbangkan antara pekerjaan dan mengasuh anak autisme. Individu juga melakukan adaptasi 
dengan menjalankan peran ganda sebagai ayah dan ibu. Selain dukungan yang diberikan dari lingkungan, karakteristik internal individu juga sangat berpengaruh. Keterbukaan dan memiliki kemampuan sosialisasi yang baik, serta kedekatan individu dengan Tuhan menciptakan pikiran yang optimis dan menerima kondisi yang dialami.

Kondisi remaja yang memiliki gangguan autisme, ketika istri mengalami sakit menahun terdapat antisipasi grief yang dilakukan oleh kedua partisipan sehingga ketika hal tersebut berat bagi kedua partisipan namun, dapat membantu mempercepat proses resiliensi. Hal ini disebabkan adanya pengalaman sebelumnya mengenai kondisi anak autisme sehingga ketika istri mengalami sakit sudah ada persiapan saat istri meninggal. Peneliti menemukan bahwa istri kedua partisipan menjadi fondasi resiliensi bagi kedua partisipan. Hal ini dapat terlihat ketika mereka mengetahui kondisi anak mereka memiliki gangguan autisme, istri dengan tekun mencari tahu mengenai autisme dan cara memperlakukan anak autisme. Melalui ketekunan yang ditunjukkan menjadikan kedua partisipan menyadari bahwa dirinya juga harus menerima kondisi anak tersebut dan belajar untuk dapat terlibat langsung dan mengenali secara tepat perilaku yang ditunjukkan anak sehingga ayah dan ibu dapat mengikuti perkembangan anak hingga remaja. Ketika istri kedua partisipan meninggal, tidak membuat individu merasa tertekan atau mengalami kemunduran kembali dalam mengasuh remaja autisme. Hal ini disebabkan adanya proses resiliensi yang dialami kedua partisipan, yaitu sebuah proses yang dapat dipelajari individu saat menghadapi stresor. Kedua partisipan belajar melalui istri mereka masingmasing dalam menghadapi stressor memiliki remaja autisme.

Mereka mulai terbiasa dan melakukan apa yang sudah mereka lakukan selama ini sejak remaja autisme mereka masih kecil, bahkan mereka merasa lebih mandiri dan dapat mengembangkan diri mereka, serta remaja autisme dalam melatih kemandiriannya. Hal ini juga dipengaruhi oleh hubungan yang dimiliki antara ayah dan ibu. Salah satu faktor yang memengaruhi penerimaan ayah terhadap remaja autisme adalah status pernikahan yang harmonis (Sarasvati, 2004). Hal ini akan memudahkan suami istri untuk saling membantu dalam menghadapi situasi sulit yang dialami. Kedua partisipan juga menunjukkan penerimaan melalui perhatian dan kasih sayang yang diberikan. Pasca menjadi ayah tunggal membuat mereka lebih banyak meluangkan waktu dan memperhatikan perkembangan remaja secara mandiri. Hal ini sesuai dengan Hurlock (2007) mengatakan bahwa penerimaan ayah terhadap remaja autisme ditandai dengan perhatian yang besar dan kasih sayang pada anak tersebut. Ayah akan tetap memperhatikan perkembangan kemampuan dan memperhatikan minat remaja yang menderita autisme.

Active coping yang dilakukan kedua partisipan adalah berdoa dan mendekatkan diri kepada Tuhan. Kedua partisipan selain mengandalkan terapi juga membawa remaja autisme ke gereja dengan harapan remaja autisme dapat kembali normal. Kepercayaan yang dimiliki kedua partisipan menjadi peran besar dalam proses resiliensi individu. Hal serupa diungkapkan oleh Nelson (2009) bahwa religi menyumbangkan hal penting dalam memunculkan perasaan emosi positif. Pengalaman emosi yang berhubungan dengan religi, yaitu adanya perasaan damai, perasaan untuk memiliki insight ketika menghadapi masalah, dan kebahagiaan. Fase remaja merupakan masa tidak lagi berhubungan hanya dengan individu dari jenis kelamin yang sama tetapi dengan lawan jenis. Dalam pemenuhan kebutuhan seksualitas, remaja autis memiliki ketertarikan pada orang lain, tetapi gaya ekspresi seksualitas mereka seringkali naif, tidak matang dan tidak sesuai dengan usianya (Schwier \& Hingsburger, dalam Dariany 2015). Hal ini tidak sesuai dengan kedua remaja partisipan belum terlihat adanya ketertarikan dengan lawan jenis.

Kondisi finansial keluarga juga ambil bagian dalam ayah tunggal beradaptasi dan menerima kondisinya (Sarasvati, 2004). Individu perlu menyeimbangkan antara pekerjaannya untuk memenuhi kebutuhan keluarga tetapi disatu sisi individu perlu hadir dalam mengasuh remaja autisme terlebih kebutuhan dan perhatian yang lebih untuk remaja autisme. Keadaan finansial keluarga yang lebih baik

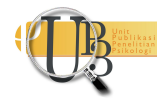


meningkatkan kemungkinan ayah untuk mampu menyediakan segala sarana dan fasilitas yang dapat digunakan untuk terapi dan usaha lainnya dengan lebih optimal. Pengalaman yang dimiliki partisipan kedua, ia tidak memiliki bantuan caregiver untuk mengasuh remaja autisme. Kondisi tersebut menuntut partisipan kedua untuk tetap bekerja agar dapat memenuhi kebutuhan anak-anaknya yang sudah memasuki masa remaja dan dewasa. Keterbatasan yang terdapat dalam penelitian ini adalah ketersediaan partisipan dengan kriteria yang sesuai dengan penelitian ini. Peneliti kesulitan untuk mencari komunitas bagi ayah tunggal yang memiliki remaja dengan gangguan autisme. Berdasarkan hasil wawancara, ayah tunggal lebih memilih untuk menghabiskan waktu dengan anak-anak mereka atau mencari suatu kegiatan yang menghasilkan uang dibanding bergabung dalam sebuah komunitas.

\section{S I M P U L A N}

Kesimpulan dari penelitian ini adalah karakteristik internal, lingkungan eksternal, dan faktor-faktor sampingan yang berperan dalam proses resiliensi partisipan. Faktor sampingan yang dimaksud adalah adanya caregiver yang dapat membantu partisipan dalam mengasuh remaja autisme. Proses resiliensi kedua partisipan terjadi ketika anak mereka mendapat diagnosa autisme hingga saat ini menjadi ayah tunggal. Selain itu, terdapat antisipasi grief ketika istri sakit. Hal tersebut dapat mempercepat proses resiliensi kedua partisipan ketika istri meninggal. Faktor-faktor protektif yang paling berpengaruh adalah dukungan keluarga, teman-teman, dan komunitas gereja. Karakteristik internal yang dimiliki kedua partisipan adalah aspek spiritual, yaitu kedekatannya dengan Tuhan. Kedua partisipan memiliki fondasi resiliensi yang dimiliki oleh istri masing-masing partisipan. Hal ini membantu partisipan dalam proses resiliensi yang dialami. Kedua partisipan mengalami proses interaksi antara karakteristik internal dengan lingkungan eksternal sehingga memiliki strategi-strategi. Active coping kedua partisipan ditunjukan dengan berdoa dan bercerita kepada teman. Cognitive reframing dengan mengubah pemikiran melalui stresor yang dihadapi menjadi lebih positif. Selective perception kedua partisipan ditunjukan dengan mengabaikan desakan menikah kembali. Sedangkan, environmental modification digunakan oleh kedua partisipan untuk mengubah layanan remaja dan bagi Mikael mengubah tempat kerja. Kedua partisipan memiliki adaptasi positif dengan tingkat resilient reintegration. Kedua partisipan mampu menjalankan tugas perkembangan yang meningkat sebagai ayah tunggal melalui penerimaannya pada remaja autisme, mengetahui potensi yang dimiliki dalam mengurus rumah tangga dan mengasuh remaja autisme, memiliki keterbukaan dengan orang lain, dan memiliki komunikasi dan hubungan yang baik dengan anak-anak serta orang lain, mampu menyeimbangkan tuntutan pekerjaan dan mengasuh remaja autisme.

Melalui penelitian ini, peneliti menemukan adanyanya sejumlah saran yang dapat mendukung pengembangan metodologis pada penelitian selanjutnya, antara lain karakteristik partisipan penelitian dapat lebih bervariasi, tidak hanya ayah tunggal yang memiliki remaja dengan gangguan autisme. Usia anak autisme saat menjadi ayah tunggal sebagai karaktersitik partisipan yang akan dilibatkan. Hal tersebut dimaksud untuk melihat perbedaan dan persamaan pola resiliensi antara menjadi ayah tunggal ketika usia anak dini yang memiliki gangguan autisme dengan menjadi ayah tunggal ketika anak usia remaja sehingga mungkin akan didapatkan variasi atau hasil berbeda yang pada akhirnya dapat memperkaya penelitian dengan topik yang sama. Selain itu, peneliti melakukan triangulasi data dengan melakukan wawancara hanya kepada caregiver anak autisme. Pada penelitian selanjutnya mungkin dapat melakukan triangulasi data kepada teman dekat atau keluarga yang mengetahui kondisi partisipan atau sebagai tempat untuk mengekspresikan emosinya sehingga data yang didapat akan lebih kaya. Apabila peneliti ingin melanjutkan penelitian ini dengan kriteria yang bertambah, akan lebih baik apabila peneliti menyiapkan waktu yang lebih lama untuk mencari partisipan yang sesuai dengan kriteria. Peneliti dapat mendekatkan diri atau menjadi sukarela dalam komunitas yang sesuai dengan kriteria penelitian agar lebih banyak pendapat jumlah partisipan.

INSAN Jurnal Psikologi dan Kesehatan Mental

2021, Vol. 6(1), 22-43

doi: 10.20473/jpkm.v6i12021.22-42 
Saran praktis yang dapat diberikan peneliti agar dapat memahami tentang proses resiliensi ayah tunggal yang memiliki anak autisme, yaitu keterlibatan ayah secara aktif dalam mengasuh anak sangat dibutuhkan. Hal tersebut diperlukan agar ayah dapat mengenali cara yang tepat untuk menanggapi perilaku anak secara konsisten sehingga ibu merasa mendapat dukungan dan dapat membantu satu sama lain. Harmonisasi hubungan suami istri sangat diperlukan sedini mungkin sebagai persiapan jika salah satu pasangan meninggal dunia sehingga masing-masing individu mengetahui peran ganda yang harus dijalankan. Selain itu, penting bagi orangtua untuk mempersiapkan caregiver pengganti dirinya untuk remaja autisme. Hal ini dilakukan agar terdapat antisipasi apabila terjadi sesuatu dengan orangtua dari remaja autisme. Bagi pihak keluarga dan teman diharapkan untuk tetap memberikan dukungan, membantu mencari informasi mengenai remaja autisme, serta memberikan perhatian secara langsung kepada remaja autisme. Pihak keluarga besar dan teman juga harus dapat mengerti dan menjadi tempat untuk individu mengekspresikan emosinya sehingga dapat membantu individu merasa lega. Komunitas ayah tunggal yang memiliki remaja dengan gangguan autisme merupakan hal yang penting. Hal ini dapat menjadi tempat untuk ayah tunggal saling mendukung, mendengarkan keluh kesah, dan berbagi informasi mengenai layanan-layanan yang dapat mendukung perkembangan remaja autisme.

\section{UCAPAN TERIMA KASIH}

Puji dan syukur saya panjatkan kepada Tuhan atas berkat serta penyertaan-Nya dari awal hingga kami dapat menyelesaikan penelitian ini. Para partisipan yang bersedia untuk mengambil bagian dalam pembuatan penelitian ini, terima kasih untuk waktu dan kesediaannya untuk membagikan kisah hidupnya. Yapina Widyawati, M.Psi., Psikolog dan M. Triwarmiyati D.W.S.Sos., M.Si sebagai expertise di bidang resiliensi. Terima kasih untuk waktu dan feedback yang diberikan dalam penyusunan panduan wawancara. Fransisca Rosa Mira Lentari, S.Psi., Psi terima kasih sudah bersedia meminjamkan sumber literatur dan beberapa masukan yang sangat berguna dalam penelitian ini. Harjono, SE sebagai commissioner Miracle therapy centre, Josephine Thea Gracia, dan Jounne Marryday H. M. yang mengenalkan peneliti kepada partisipan. Artikel ini telah dipresentasikan secara lisan dalam Temu Ilmiah nasional Himpunan Psikologi Indonesia di Bandung, 7-8 September 2018. Kami berharap semoga penelitian ini dapat berguna nantinya, terutama bagi ayah tunggal dikarenakan istri meninggal dan memiliki remaja dengan gangguan autisme. Semoga penelitian ini dapat memberikan pengaruh positif bagi mereka. Kami juga berharap penelitian ini dapat memberikan pandangan dan pemikiran baru bagi masyarakat, terutama mengenai ayah tunggal dengan remaja autisme. Akhir kata kami berharap penelitian ini dapat berguna bagi semua pihak yang membutuhkan.

\section{DEKLARASI POTENSI TERJADINYA KONFLIK KEPENTINGAN}

Jannes Dinda Tricia dan Penny Handayani tidak bekerja, menjadi konsultan, memiliki saham, atau menerima dana dari perusahaan atau organisasi manapun yang mungkin akan mengambil untung dari diterbitkannya naskah ini.

\section{PUSTAKA ACUAN}

Andri, A. (2009). Interaksi antara ayah dengan anak dalam keluarga Single Parent. Skripsi Sosiologi. Universitas Indonesia.

Apostelina, E. (2012). Resiliensi keluarga pada keluarga yang memiliki anak autis. Jurnal Penelitian dan INSAN Jurnal Psikologi dan Kesehatan Mental

2021, Vol. 6(1), 22-43

doi: 10.20473/jpkm.v6i12021.22-42 
Pengukuran Psikologi, 1, 1, 164-176.

Berk, L. E. (2012). Development Through the Lifespan: Edisi kelima. Yogyakarta: Pustaka Pelajar.

Burrell, A., Ives, J., \& Unwin, G. (2017). The experiences of fathers who have offspring with autism spectrum disorder. J autism dev disord 47: 1135-1147.

Christieny, A. R. (2016). Deskripsi pengalaman ayah sebagai orang tua tunggal dalam melalui proses resiliensi. Universitas Sanata Dharma Yogyakarta.

Creswell, J. W. (2012). Educational research: planning, conducting, and evaluating quantitative and qualitative research fouth edition. Boston: Pearson Education, Inc.

Dariany, D. (2015). Pada orangtua yang memiliki anak tunggal remaja autis. Fakultas Psikologi Universitas Katolik Widya Mandala, Surabaya.

Glantz, M. D. \& Johnson, J. L. (2002). Resilience and development: Positive life adaptations. New York: Kluwer Academic.

Hallahan, D.P \& Kauffman, J.M. (2006). Exceptional learners. An introduction to special education. (10th ed.) Massachusetts: Allyn asnd Bacon.

Hurlock, E.B. (2007). Psikologi perkembangan: suatu pendekatan sepanjang rentang kehidupan). Jakarta: Erlangga.

Isa, S. N. I., et al. (2016). Perceived stress among malay caregivers of children with learning disabilities in kelantan. Jurnal Sains Kesihatan Malaysia, 14, 2, 69-77.

Lamb, M., E. (2010). The Role of the father in child development. New York: Wiley.

Pisula, E. (2011). Parenting stress in mothers and fathers of children with autism spectrum disorders, A Comprehensive Book on Autism Spectrum Disorders, Dr. Mohammad-Reza Mohammadi (Ed.), ISBN: 978- 953-307-494-8, InTech, Available from: http://www.intechopen.com/books/acomprehensive-book-on-autism- spectrum-disorders/parenting-stress-in-mothers-and-fathersof-children-with-autism-spectrum-disorders

Poerwandari, E. K. (2013). Pendekatan kualitatif dalam penelitian psikologi. Jakarta: LPSP3 FP-UI.

Santrock, J.W. (2003). Life-span development $14^{\text {th }}$ ed. New York: McGraw-Hill.

Sarasvati. (2004). Meniti pelangi perjalanan seorang ibu yang tak kenal menyerah dalam membimbing putranya keluar dari belenggu adhd dan autisme. Jakarta: PT. Elex Media Komputindo.

Singh, K., Junnarkar, M., \& Kaur, J. (2016). Measures of positive psychology: development and validation. India: Spinger.

Wiludjeng, J. M. H. (2013). Orang tua tunggal: permasalahan dan solusinya. Jakarta: Inti Prima. 